\title{
SPATIAL DIVERSITY OF AGRICULTURAL AREAS WITH NO ACCESS TO ROADS IN VILLAGES OF COMMUNE OF BILGORAJ
}

\author{
Przemyslaw Len \\ University of Life Sciences in Lublin, Poland \\ przemyslaw.len@up.lublin.pl
}

\begin{abstract}
Agricultural transport roads play an important role not only from the point of view of individual farm holdings, but also the general development of rural areas. Roads constitute an element of the technical infrastructure indispensable for communication and transport; they play a role in shaping the rural landscape, and the routes they follow affect the forms and size of agricultural land and forest areas found within the area covered by a given road system. The existing public road network does not always provide access to all fields. Farming on parcels without road access is connected with very high crop production costs, and the necessity to pass through plots belonging to other owners is a source of additional losses and, sometimes, conflicts with neighbours. The aim of this article was to present the values of the synthetic measure obtained in the study that allowed us to identify groups of villages, which differed in terms of access of parcels to roads. The ranking was established using the zero unitarisation method. This method makes it possible to standardize diagnostic variables by examining the range of a feature. The research area encompassed 30 villages with a total area of 26258.72 ha, divided administratively into 45525 land parcels (cadastral plots). The types of villages identified in the study vary in terms of access of parcels to roads, which may be considered as one of the criteria for determining the order in which the villages should be subjected to land consolidation and exchange. Information regarding the number of parcels with no road access is one of the most important components of the assessment of the demand for land consolidation in the area under study. By definition, land consolidation measures are intended to improve and rearrange the transport network (in particular the network of agricultural transport roads) and create conditions allowing farmers legal access to plots. Free access to fields contributes to viable and profitable agricultural production.
\end{abstract}

Keywords: land consolidation, rural areas, defective spatial structure of agricultural land.

\section{Introduction}

Activities aimed at the improvement of instruments of rural development have been undertaken in Europe for many years. Those focusing on the changing the ownership structure, implemented through the traditional process of land consolidation, are gradually replaced by multifunctional activities for rural development, considering elements of environmental protection, agricultural landscape management, and solutions concerning soil and water protection. Such development must be accompanied by the application of new pro-ecological design and material-technological solutions regarding the construction of rural roads. The roads should be designed with possibly the fullest consideration of a rich resource of data on a given area, performance of many spatial analyses, and decision making in the scope of selection of the most appropriate solutions acceptable to all stakeholders (e.g., residents, farmers, local authorities, entrepreneurs, and investors) [1].

One of the factors, which affect crop production costs, is the spatial arrangement of farmland in agricultural holdings, which may be influenced by the layout of buildings and access roads, as well as the size of the village and the farm. The distance from the farmstead to the farming plots should be no longer than $0.5-1.0 \mathrm{~km}$ in the case of concentrated settlement. In actuality, however, fields can be located as far as several kilometres away from the farmstead. The necessity to travel such long distances generates considerable costs, with a farmer who has to travel one kilometre to his/her field losing up to $10 \%$ of the crop production profit [2].

One way of reducing the distance from farmstead to field is to improve the layout of the transport network by introducing land consolidation and exchange measures. The decisions taken as part of a consolidation project have a huge impact on the costs of transporting agricultural machines, production materials, and crops. They also affect the aesthetics and functionality of the agricultural landscape. Moreover, land management interventions provide the possibility of reclaiming agriculturally useless land, i.e. finding alternative uses for the so-called problem areas of agriculture $[3 ; 4]$ and improving a defective spatial structure, characterized by large scattering of privately-owned farmland [5], as well as a high degree of fragmentation [6; 7]. Land consolidation contributes to the establishment of a proper real estate cadastre [8-16]. 
To avoid mistakes in transforming the landscape, prior to consolidation, the existing roads should be thoroughly assessed for their technical condition and spatial layout from the perspective of their current and prospective suitability for agricultural transport. The roads have to be assessed quantitatively and qualitatively, and the shortest distances from farmsteads to farmland have to be determined. When the existing road system is assessed as being poor, then its transformation consists in [17]:

- providing every parcel with access to the farmstead,

- adjusting the density of the road network to the newly created spatial structure of land,

- making sure that each parcel has access to as many roads as possible,

- removing obstacles to the movement of agricultural machines and special purpose agricultural vehicles (narrow roads, difficult bends, etc.),

- adapting the routes to the existing landforms and the system of water drainage facilities.

- Another important factor affecting the impact of road accessibility on the costs of crop production is the arrangement of fields in relation to roads. There are two basic field access layouts:

- two-sided, in which parcels are situated between two roads and can be accessed from two sides from all roads,

- one-sided, in which a parcel adjoins the road at one of its shorter sides, while the other side adjoins the neighbouring field [9].

For parcels of small lengths (up to $180 \mathrm{~m}$ ), the crop production costs related to the arrangement of farmland are higher for parcels with two-sided access compared to those with one-sided access. For longer plots (150-200 m), an opposite relationship is observed. This means that, in order to prevent an increase in crop production costs, long plots should be provided with two-sided road access [18].

The aim of this present article was to investigate the differences in the spatial structure of the villages located in the Biłgoraj commune in the Lublin Province, which have no direct connection to the road network. A map showing the geographical situation of the commune of Bilgoraj is presented in Fig. 1.

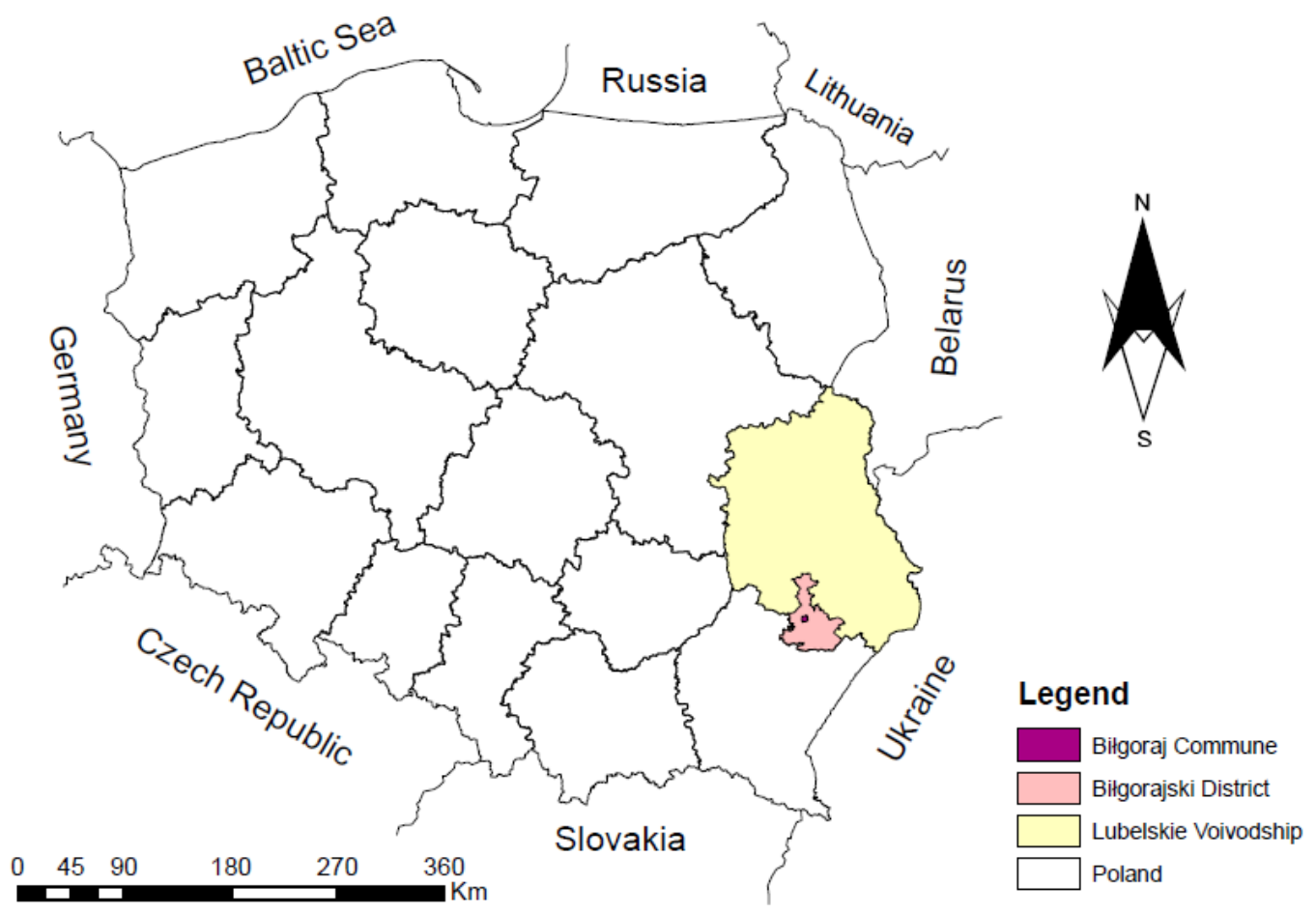

Fig. 1. Geographical situation of study area

The investigated commune encompasses 30 villages (excluding the village of Teodorówka - no cadastre data) occupying a total area of $26258.72 \mathrm{ha}$. The area is administratively divided into 45525 cadastral plots. The types of villages identified in the study vary in terms of road access, which may be 
considered as one of the criteria for determining the order in which the villages should be subjected to land consolidation and exchange.

\section{Materials and methods}

Firstly, the percentage of parcels without direct access to public roads and the percentage of area occupied by the parcels without direct road access were determined for each village using GIS tools. The analysed parcels were serviced by roads located in

the neighbouring cadastral communities. The factors obtained were used to create a ranking, which enabled us to determine the differences in the spatial structure among the examined villages, which had no connection to the road network.

Four factors were used to create the ranking: $x_{1}$ - total area of a village, $x_{2}-$ total number of parcels, $x_{3}$ - percent of parcels with no road access, and $x_{4}$ - percent of the area occupied by parcels without access to a road. The ranking was established using the zero unitarisation method. This method makes it possible to standardize diagnostic variables by examining the range of a feature [19]. The diagnostic variables, which describe a given object, can be divided into three groups [20]:

1. stimulants - variables which increase in value leads to an increase in the value of a diagnostic feature of the object under consideration; in this case, standardized variables are calculated from the following formula:

$$
Z=\frac{\left(x-x_{\min }\right)}{\left(x_{\max }-x_{\min }\right)}
$$

2. destimulants - variables which increase in value leads to a decrease in the value of a diagnostic feature of the object under consideration; in this case, standardized variables are calculated from the following formula:

$$
Z=\frac{\left(x_{\max }-x\right)}{\left(x_{\max }-x_{\min }\right)}
$$

3. nominants - variables that only for a certain value or range of values take the highest rating (optimum); as we move away from the optimum, the evaluation of the phenomenon decreases, then the normed variables are calculated according to:

$$
\begin{aligned}
& Z=\frac{\left(x-x_{\min }\right)}{\left(x_{o p t}-x_{\min }\right)}, \text { for } x<x_{\mathrm{opt}}, \\
& Z=\frac{\left(x-x_{\max }\right)}{\left(x_{o p t}-x_{\max }\right)}, \text { for } x>x_{\mathrm{opt}},
\end{aligned}
$$

where $z$-standardized variable;

$x$ - variable prior to standardization;

$x_{\max }$ - maximum value of a variable in a given set;

$x_{\min }$ - minimum value of a variable in a given set;

$x_{\mathrm{opt}}$ - optimal value of the variable in a given set.

The standardization of diagnostic features is a preliminary step, which leads to a consolidated multi-criteria evaluation of each of the objects under consideration. The consolidated evaluation of each object is obtained by aggregation. In order to obtain a synthetic measure, average values of the sets characterizing the respective features are calculated using the following formula:

$$
z_{i}=\frac{1}{p} \sum_{j=1}^{p} x_{i j} \quad(\mathrm{i}=1, \ldots \mathrm{n}) .
$$

Standardized measures are in the range $<0 ; 1>$. The results are interpreted as the average of the optimum values achieved by each object. Accordingly, the higher the value of the synthetic measure, the higher the position of the object in the ranking. 


\section{Results and discussion}

The values of the synthetic measure obtained in the study allowed us to identify groups of villages, which differed in terms of access of parcels to roads.

Table 1

Ranking of villages by access of fields to the public road network

\begin{tabular}{|c|c|c|c|c|c|}
\hline $\begin{array}{c}\text { Position } \\
\text { in the } \\
\text { ranking }\end{array}$ & $\begin{array}{c}\text { Value of } \\
\text { synthetic } \\
\text { measure }\end{array}$ & Name of village & $\begin{array}{c}\text { Position } \\
\text { in the } \\
\text { ranking }\end{array}$ & $\begin{array}{c}\text { Value of } \\
\text { synthetic } \\
\text { measure }\end{array}$ & Name of village \\
\hline 1 & 0.5720 & Sól & 16 & 0.1873 & Dyle \\
\hline 2 & 0.5284 & Majdan Gromadzki & 17 & 0.1870 & Hedwiżyn \\
\hline 3 & 0.3645 & Nadrzecze & 18 & 0.1828 & Bidaczów Stary \\
\hline 4 & 0.3360 & Korytków Duży & 19 & 0.1745 & Rapy Dylańskie \\
\hline 5 & 0.3291 & Gromada & 20 & 0.1685 & Andrzejówka \\
\hline 6 & 0.3229 & Wola & 21 & 0.1550 & Ignatówka \\
\hline 7 & 0.2905 & Dąbrowica & 22 & 0.1517 & Wolaniny Rawica \\
\hline 8 & 0.2752 & Kajetanówka & 23 & 0.1478 & Brodziaki \\
\hline 9 & 0.2659 & Ciosmy & 24 & 0.1449 & Bidaczów Nowy \\
\hline 10 & 0.2583 & Bukowa & 25 & 0.1416 & Wola Dereźniańska \\
\hline 11 & 0.2475 & Bukowina Las & 26 & 0.1405 & Dereźnia Solska \\
\hline 12 & 0.2348 & Dereźnia Zagrody & 27 & 0.0979 & Edwardów \\
\hline 13 & 0.2308 & Korczów & 28 & 0.0960 & Ruda Zagrody \\
\hline 14 & 0.2306 & Smólsko Duże & 29 & 0.0837 & Ruda Solska \\
\hline 15 & 0.2020 & Dereźnia Majdańska & 30 & 0.0646 & Smólsko Małe \\
\hline
\end{tabular}

The analysis of the results obtained for the villages of the commune of Biłgoraj allowed us to create a ranking, which showed that there were differences among the villages in the access of farmland to the previously defined road network. A map showing these differences is given in Fig. 2 .
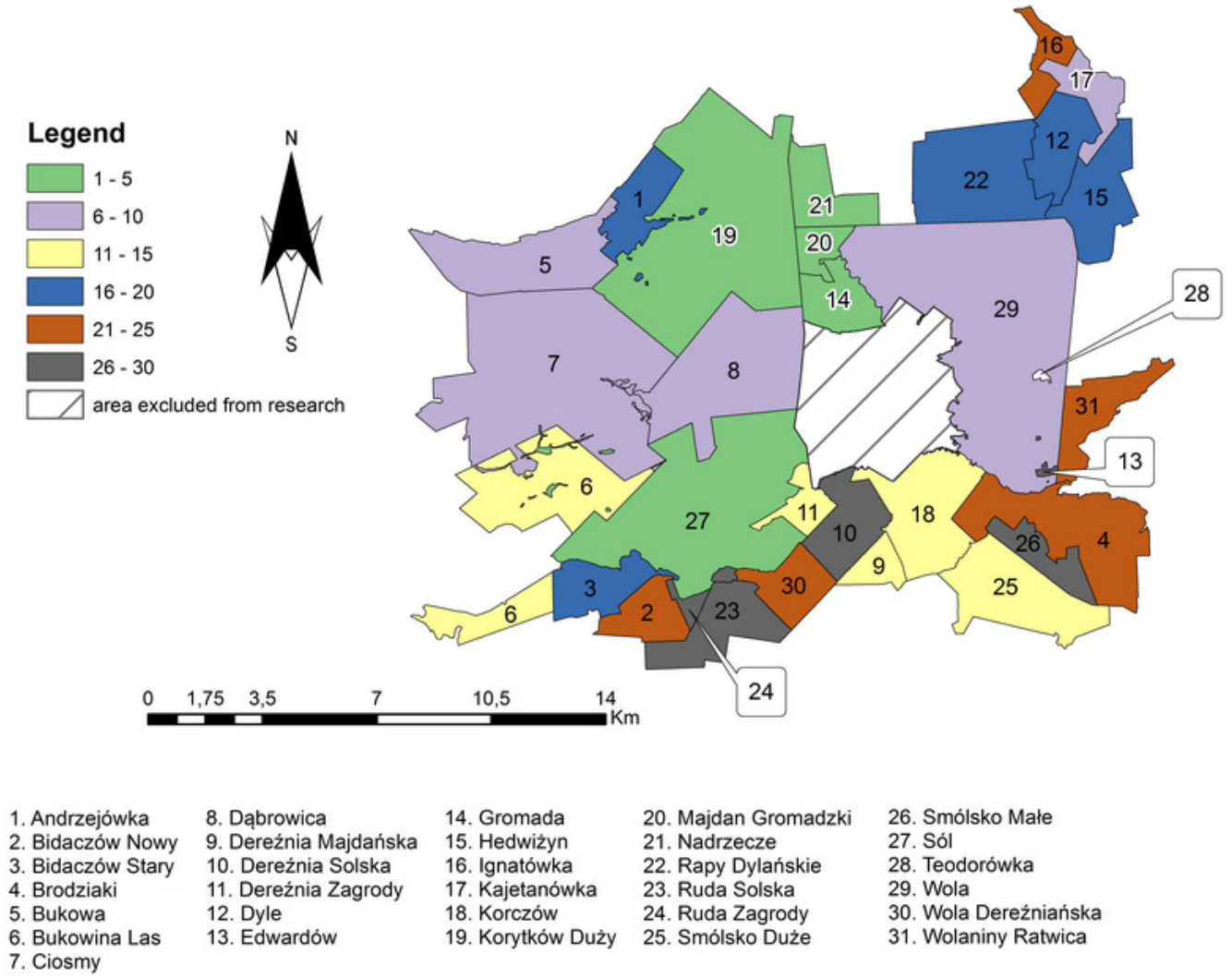

20. Majdan Gromadzki 21. Nadrzecze 22. Rapy Dylańskie

23. Ruda Solska

24. Ruda Zagrody

25. Smólsko Duże
26. Smólsko Małe 27. Sól 28. Teodorówka 29. Wola

30. Wola Dereźniańska 31. Wolaniny Ratwica

Fig. 2. Differences in spatial structure of villages of Biłgoraj commune with regard to prevalence of areas with poor road access 
In the investigated administrative district, the lack of roads providing access to parcels is a grave issue, which requires the introduction of land management measures. Land consolidation should be carried out in the order shown in Table 1. The villages in Fig. 2 are clustered in groups that indicate which areas should be consolidated first. Because the values of the synthetic measure are similar for neighbouring villages, it is advisable to implement land consolidation projects in several villages at the same time. Such a strategy will facilitate and accelerate land management activities. In addition, it will create an opportunity to remove other existing defects, e.g. regulate the irregular boundaries between villages.

\section{Conclusions}

4. The road transport system plays a particularly important role in the proper functioning of farm holdings.

5. Appropriately arranged roads, which can accommodate internal agricultural transport, should provide direct access to each separately cultivated plot and a connection to the farmstead.

6. The present study regarding the differences in the spatial structure of agricultural areas in the Biłgoraj commune, which have no access to a public road, provides important data for the prioritization of land consolidation activities in this administrative district.

7. Our results show that the lack of access to plots is a large problem in the Biłgoraj commune.

8. This observation points not only to the need for land management interventions in this rural area, but also the large costs, which need to be incurred in constructing a new road network.

9. The values of the synthetic measure obtained in the study allowed us to identify groups of villages, which differed in terms of access of parcels to roads.

10. The analysis of the results obtained for the villages of the commune of Biłgoraj allowed us to create a ranking, which showed that there were differences among the villages in the access of farmland to the previously defined road network.

11. The development of modern transport means should be accompanied by modernization and restructuring of the road network in rural areas, because their poor technical condition hinders and sometimes prevents the efficient use of the transport resources at the disposal of farm owners.

\section{References}

[1] Krupowicz W., Sobolewska-Mikulska K., Burinskiene M. Modern trends in road network development in rural areas. Baltic Journal of Road and Bridge Engineering Vol. 12, (1), pp. 48-56. DOI: 10.3846/bjrbe.2017.06.

[2] Harasimowicz S., Janus J., Ostrągowska B. Optymalizacja przydziału gruntów do gospodarstw i jej powiązanie ze strefami różnic odległości z siedlisk do działek (Optimal allocation of farmlands to farms and linking the allocation with the zones of differences in distances between farm sites and plots). Infrastruktura i Ekologia Terenów Wiejskich. Nr 2009/ 05. PAN, Kraków 2009, pp. 93-94. (In Polish)

[3] Wójcik-Leń J., Sobolewska-Mikulska K., 2017a. Specific features of development of selected agricultural problematic areas in the land consolidation process. Journal of Water and Land Development. No. 34 pp. 249-258. DOI: 10.1515/jwld-2017-0060.

[4] Wójcik-Leń J., Sobolewska-Mikulska K., 2017b. Issues related to marginal lands with reference to selected agricultural problematic areas. Journal of Water and Land Development. No. 35 pp. 265-273. DOI: 10.1515/jwld-2017-0093.

[5] Strek Z. 2017. Engineering for rural development analysis of demand for land consolidation in Milejów commune, Łęczna district. Engineering For Rural Development, Jelgava, 24.26.05.2017, pp. 593-599, DOI: 10.22616/ERDev2017.16.N119.

[6] Leń P., Król Z. Analysis of economic and environmental effects of land consolidation on the example of Hucisko village . Journal of Ecological Engineering. Volume 17, Issue 5, Nov. 2016, pp. 232-239. DOI: 10.12911/22998993/65090.

[7] Wójcik-Leń J., Stręk Ż. Proposal for land consolidation project solutions for selected problem areas. World Multidisciplinary Earth Sciences Symposium (WMESS 2017). Earth and Environmental Science 95, 2017, 032016. DOI :10.1088/1755-1315/95/3/032016. 
[8] Dawidowicz A. Kulawiak M. 2017. The potential of Web-GIS and Geovisual Analytics in the context of marine cadastre. Survey Review, DOI: 10.1080/00396265.2017.1328331

[9] Dawidowicz A., Źróbek R. 2018. A methodological evaluation of the Polish cadastral system based on the global cadastral model. Land Use Policy 73, 2018, pp. 59-72. DOI: 10.1016/j.landusepol.2018.01.037

[10] Karabin M. 2012. Registration of untypical 3D objects in Polish cadastre - do we need 3D cadastre? Geodesy and Cartography. 2012. vol. 61, No 2, pp. 61-71. DOI:10.2478/v10277-0120023-8.

[11] Mika M. 2016. Proposals for changes in surveying-legal procedures for the needs of cadastre in Poland. Reports on Geodesy and Geoinformatics Volume: 102 Issue: 1 pp. 67-77

[12] Mika M. 2017. Interoperability cadastral data in the system approach .Journal of Ecological Engineering Vol. 18(2), pp. 150-156.

[13] Mika M., Len P. Analysis of the faulty spatial structure of land in the context of assessing the quality of cadastral data in Poland, 16th International Multidisciplinary Scientific GeoConference SGEM 2016, www.sgem.org, SGEM2016 Conference Proceedings, 28 June - 6 July 2016, Book2, 2: pp. 91-100.

[14] Mika M., Siejka M., Leń P., Król Ż. 2016. The concept of using the water cadastre databases components for the construction of multidimensional cadastre in Poland, Survey Review, pp. 1-11. DOI: 10.1080/00396265.2016.1263180.

[15] Noszczyk T., Hernik J. Kompleksowa modernizacja ewidencji gruntów i budynków [Modernization of the land and property register]. Acta Sci. Pol. Formatio Circumiectus 15 (1) 2016, pp. 3-17.

[16] Siejka M., Ślusarski, M., Mika M. Legal and technical aspects of modernization of land and buildings cadastre in selected area, Reports on Geodesy and Geoinformatics, vol. 99/2015, pp. 44-53.

[17] Radziszewska W., Jaroszewicz J. Ocena istniejącej sieci dróg transportu rolnego na obszarze wsi poddanej pracom scaleniowym [Analysis of the existing agricultural road network of a village prior to undergoing land consolidation]. Acta Scientiarum Polonorum Geodesia et Descriptio Terrarum, 11(3) 2012, p.17-19.

[18] Harasimowicz S., Janus J., Ostrągowska B. Wpływ długości działek na ich dostępność z dróg i jego wykorzystanie do korekty dróg rolniczych [Effect of length of farm plots on their accessibility from farm roads and using this effect while correcting farm roads]. Infrastruktura $\mathrm{i}$ Ekologia Terenów Wiejskich. Nr 2012/ 01. PAN, Kraków 2012, p. 170.

[19] Jędrzejczyk Z., Kukuła K., Skrzypek J., Walkosz A. Badania operacyjne w przykładach i zadaniach (Operations research: Examples and tasks), Wydawnictwo Naukowe PWN, Warszawa, 2002. (In Polish)

[20] Kukuła K. Metoda unitaryzacji zerowanej (The zero unitarization method), PWE, Warszawa, 2000. (In Polish) 